\title{
Remediation efficiency of three treatments on water polluted with endocrine disruptors: Assessment by means of in vitro techniques
}

\author{
Juliana Polloni-Silva ${ }^{\mathrm{a}, \mathrm{b}}$, Ana Valdehita ${ }^{\mathrm{a}}$, Renata Fracácio ${ }^{\mathrm{b}}$, José M. Navas ${ }^{\mathrm{a}}{ }^{*}$ \\ a Department of Environment, Spanish National Institute for Agricultural and Food Research and Technology (INIA), Ctra. De la Coruña Km 7.5, E-28040, \\ Madrid, Spain \\ b São Paulo State University “Júlio de Mesquita Filho" (UNESP), Sorocaba Campus, Avenida Três de Março, 511, Bairro: Alto da Boa Vista, 18087-180, \\ Sorocaba, Brazil
}

\section{H I G H L I G H T S}

- Different substrates were used to remove endocrine disrupters (EDs) from waters.

- Activated carbon (AC) retired efficiently EDs from laboratory prepared waters.

- AC did not show a good performance in the treatment of effluent samples.

- Zeolite (ZEO) was assayed as a substrate for the removal of EDs.

- ZEO allowed the reduction of androgenic activity in actual wastewaters.

\section{A R T I C L E I N F O}

\section{Article history:}

Received 3 June 2016

Received in revised form

25 November 2016

Accepted 4 January 2017

Available online 4 January 2017

Handling Editor: Frederic Leusch

\section{Keywords:}

Androgenicity

Estrogenicity

In vitro assays

Remediation

Water treatment
G R A P H I C A L A B S T R A C T

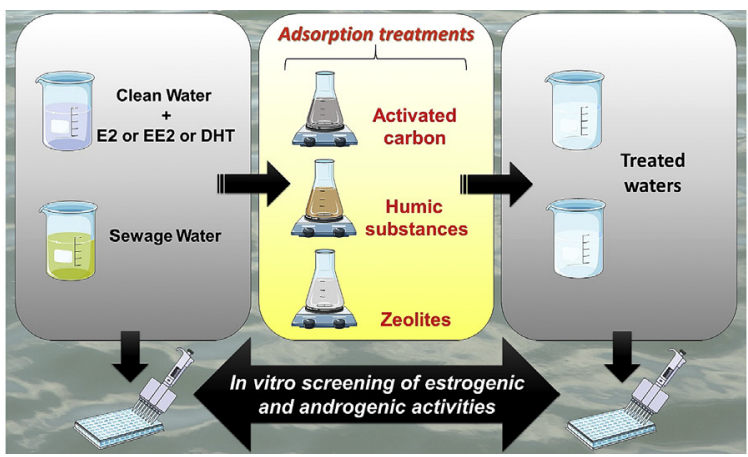

\begin{abstract}
A B S T R A C T
Chemical substances with potential to disrupt endocrine systems have been detected in aquatic environments worldwide, making necessary the investigation about water treatments able to inhibit such potential. The present work aimed to assess the efficiency for removing endocrine disruptors (with estrogenic and androgenic activity) of three simple and inexpensive substrates that could be potentially used in sectors or regions with limited resources: powdered activated carbon (PAC), powdered natural zeolite (ZEO) (both at a concentration of $500 \mathrm{mg} \mathrm{L}^{-1}$ ) and natural aquatic humic substances (AHS) (at $30 \mathrm{mg} \mathrm{L}^{-1}$ ). MilliQ-water and mature water from fish facilities (aquarium water, AW), were artificially spiked with $17 \beta$-estradiol (E2), $17 \alpha$-ethinylestradiol and dihydrotestosterone. Moreover, effluent samples from waste water treatment plants (WWTP) were also submitted to the remediation treatments. Estrogenic and androgenic activities were assessed with two cell lines permanently transfected with luciferase as reporter gene under the control of hormone receptors: AR-EcoScreen containing the human androgen receptor and HER-LUC transfected with the sea bass estrogen receptor. PAC was efficiently removing the estrogenic and androgenic compounds added to milliQ and AW. However, androgenic activity detected in WWTP effluents was only reduced after treatment with ZEO. The higher surface area of PAC could have facilitated the removal of spiked hormones in clean waters. However, it is possible that
\end{abstract}

Abbreviations: AHS, aquatic humic substances; AW, aquarium water; DHT, dihydrotestosterone; DHT-Eq, DHT equivalents; DMEM, Dulbecco's minimal essential medium;

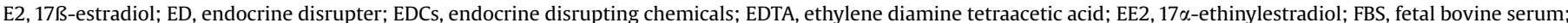

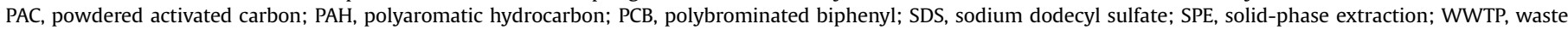
water treatment plant; ZEO, zeolite.

* Corresponding author.

E-mail addresses: ju_polloni@yahoo.com.br (J. Polloni-Silva), ana.valdehita@inia.es (A. Valdehita), rfracacio@sorocaba.unesp.br (R. Fracácio), jmnavas@inia.es (J.M. Navas). 
the substances responsible of the hormonal activity in WWTP have adsorbed to micro and nanoparticles present in suspension that would have been retained with higher efficiency by ZEO that show pores of several microns in size.

() 2017 Elsevier Ltd. All rights reserved.

\section{Introduction}

The adverse effects of endocrine disrupting chemicals (EDCs) on aquatic organisms are well documented, and are a focal point of current environmental research worldwide (Grover et al., 2011). EDCs include natural substances such as reproductive hormones (e.g. estrogens, androgens and progestogens), thyroid hormones, and corticosteroids (Scholz et al., 2013), as well as a wide range of chemicals including synthetic hormones, polycyclic aromatic hydrocarbons (PAHs), polychlorinated biphenyls (PCBs), dioxins, furans, alkylphenols, pharmaceuticals, and pesticides (Andersen et al., 1999; Combalbert et al., 2012).

It is widely accepted that the most prominent source of EDCs into the aquatic environment is via sewage treatment work effluents (Grover et al., 2011; Snyder et al., 2007; Stasinakis et al., 2008; Zhang and Zhou, 2008; Zhou et al., 2009). Residual waters of domestic origin transport a number of natural and artificial hormones (Ternes et al., 1999; Baronti et al., 2000; Ying et al., 2002) that are not completely removed by conventional treatment processes (D'Ascenzo et al., 2003; Auriol et al., 2006) reaching surface waters and affecting organisms present there, including fish. According to Dias et al. (2015) such a problem is more acute in developing countries due to the lack of appropriate treatment of waste waters.

Many advanced treatment technologies have been tested for their efficiency in further removing EDCs following secondary treatment (Grover et al., 2011). These include photodegradation (Zhang et al., 2007), chemical oxidation (Jiang et al., 2005), membrane filtration, or activated carbon (AC) adsorption (Choi et al., 2005; Snyder et al., 2007). When evaluating a range of adsorbents for EDCs, AC was found to be the most effective (Zhang and Zhou, 2005). Furthermore, AC (both powdered and granular) is effective not only for estrogenic compounds (Yoon et al., 2003; Choi et al., 2005; Zhang and Zhou, 2005; Redding et al., 2009), but also for many other types of organic pollutants, e.g. pharmaceuticals (Snyder et al., 2007). Hence it is widely promoted as a standard tertiary treatment for EDCs and other emerging pollutants. However, AC presents some disadvantages, such as the high cost of the disposal of contaminated sewage sludge. Therefore, inorganic adsorbents (e.g. zeolite) with high surface specific areas have been used as alternatives to AC (Ali and Gupta, 2006; Tsai et al., 2009).

The use of zeolites as adsorbent treatment are gaining popularity due to the low-cost and availability of raw material (i.e. fly ash) and also due to the presence of well-defined molecular and porous structure, high thermal stability, ion selectivity, ion exchange capacity, and high surface specific area (Koshy and Singh, 2016). Nevertheless, the major scientific studies in this field focus primarily on treatment of heavy metals (Petrus and Warchoł, 2005; Nascimento et al., 2009), leaving open the issue of its efficiency with respect to organic molecules like most EDCs.

Once in water systems, organic molecules, including EDCs, can dissolve but they will also interact with other substances or with particles in suspension. Aquatic humic substances (AHS) constitute the most important class of complexation agents present in the natural aquatic environment and they play a key role in the transport and behavior of EDCs (Sun et al., 2007). In a study conducted by Botero et al. (2011), it was observed that the availability of endocrine disruptors can be directly influenced by the presence of humic substances in aquatic systems. Therefore, studies about the interaction between AHS and endocrine disruptors are vital for a better understanding of the transport and availability of EDCs in the environment.

Taking all this into account, the main goal of the present work was to assess the efficiency of three simple and inexpensive treatments to remove estrogenic and androgenic activities from waste waters. Polluted waters (prepared in the laboratory or collected in the field) were allowed to interact with different substrates (powdered activated carbon - PAC, powdered natural zeolite - ZEO, and AHS) that could potentially be used in sectors or regions with limited resources. In vitro assays based on the use of cells stably transfected with hormonal receptors and reporter genes have been used to determine these hormonal activities in water before and after treatment. These assays can serve as a rapid, sensitive and relatively inexpensive integrative screening method to evaluate estrogenic and androgenic activities in Waste Water Treatment Plant (WWTP) effluents and receiving water courses (Jarošová et al., 2014).

\section{Material and methods}

\subsection{Chemicals}

17ß-estradiol (E2 $\geq 98 \%$ purity), $17 \alpha$-ethinylestradiol (EE2 $\geq 98 \%$ purity), dihydrotestosterone (DHT $\geq 98 \%$ purity), ethylene diamine tetraacetic acid (EDTA), sodium dodecyl sulfate (SDS) and methanol ( $\geq 99.9 \%$ purity) were purchased from Sigma-Aldrich (Madrid, Spain). Fetal bovine serum (FBS), penicillin-streptomycin $\left(10,000 \mathrm{U} \mathrm{mL}^{-1}\right)$, hygromycin, trypsin-EDTA, geneticin, ultraglutamine, and cell culture Dulbecco's minimal essential medium (DMEM) were obtained from Lonza (Barcelona, Spain). Coenzyme A hydrate (CoA) and luciferin were purchased from Sigma-Aldrich. Phenol red-free DMEM was from Pan-Biotech (Zaragoza, Spain). The stock solutions of E2, EE2, and DHT were prepared in dimethyl sulfoxide (DMSO) from Sigma-Aldrich.

\subsection{Water samples}

In this study three different kinds of water samples were used; milliQ-water; mature aquarium water (AW) collected from the INIA animal facilities housing different fish species (rainbow trout, Oncorhynchus mykiss, gold-fish, Carassius auratus); and lastly waste water treatment plant (WWTP) effluents. MilliQ-water and AW were spiked with E2 or EE2 at $100 \mu \mathrm{M}$, or with DHT at $500 \mathrm{nM}$ in order to observe the efficiency of the treatments to remove these substances. The applied concentrations of hormones were those that allowed an appropriate detection by the transfected cells used in this work that exhibited different sensitivities. WWTP effluent waters were collected in August 2015 from four WWTP processing waste water from different areas of Madrid city. Water was collected in $1 \mathrm{~L}$ amber glass bottles, and transported immediately to the laboratory. Once in the laboratory, water samples were filtered through filter paper and stored at $4{ }^{\circ} \mathrm{C}$. Extraction for the initial assessment of endocrine activity or application of treatments (see 
below) for removing such activity were performed within $48 \mathrm{~h}$ in order to avoid any degradation.

\subsection{Adsorption treatments}

Water samples were treated with three different substrates. One PAC of mineral origin (Synth, Brazil) that was applied to waters at $500 \mathrm{mg} \mathrm{L}^{-1}$. This AC has been characterized previously (de Costa et al., 2015) and exhibits a BET surface area of $542 \mathrm{~m}^{2} \mathrm{~g}^{-1}$. AHS previously extracted from the Brazilian Iguape and Itapanhaú rivers were used at $30 \mathrm{mg} \mathrm{L}^{-1}$. Finally, a clinoptilolite ZEO (from Celta Brasil, Cotia, Brazil) that was added to waters at $500 \mathrm{mg} \mathrm{L}^{-1}$. For treatment, each adsorbent was added to different water samples (milliQ or AW contaminated in laboratory with E2, EE2, or WWTP samples) and maintained for $2 \mathrm{~h}$ in constant agitation and light deprivation. Before extracting EDCs from waters the substrates were retired. In the case of PAC and AHS waters were filtered through simple laboratory filter paper. ZEO was retired by centrifugation for $10 \mathrm{~min}$ at $1250 \mathrm{~g}$ using a Gyrozen 1248R centrifuge (Gyrozen, Korea).

\subsection{Extraction of EDCs from water}

Endocrine disrupting chemicals present in waters were extracted by solid-phase extraction (SPE) following a methodology already described (Valdehita et al., 2014). These extracts were obtained from original MilliQ, AW, and WWTP effluents, from MilliQ waters and AW to which hormones were added, and from all these waters after application of treatments for the removal of endocrine activities. Briefly, the $\mathrm{pH}$ of all samples were adjusted to $\mathrm{pH} 8$ with $\mathrm{NaOH}$. Thereafter, SPE commercial Oasis HLB cartridges from Waters (Mildford, MA, USA) were preconditioned with $6 \mathrm{~mL}$ of methanol and $5 \mathrm{~mL}$ of HPLC-grade deionized water $(\mathrm{pH} 8)$ at a flow rate of $1 \mathrm{~mL} \mathrm{~min}{ }^{-1}$. After the conditioning step, $100 \mathrm{~mL}$ of water passed through the cartridges at a flow rate of $10 \mathrm{~mL} \mathrm{~min}{ }^{-1}$. Thereafter the cartridges were rinsed with $5 \mathrm{~mL}$ of deionized water $\mathrm{pH} 8$ and dried under an air stream to remove the excess of water. Finally, the retained analytes were eluted with $2 \times 4 \mathrm{~mL}$ of methanol at $1 \mathrm{~mL} \mathrm{~min}^{-1}$. The extracts were evaporated until dryness using a vacuum dry system (miVac Duo concentrator, Genevac, Spain). The samples were then reconstituted with $300 \mu \mathrm{L}$ of methanol and stored at $-20^{\circ} \mathrm{C}$ until analysis in the in vitro assays (maximal $24 \mathrm{~h}$ thereafter). Recovery tests were designed to evaluate the efficiency of the extraction method. For that, $300 \mu \mathrm{L}$ of a solution of $100 \mu \mathrm{M} \mathrm{E2}, 100 \mu \mathrm{M}$ EE2, and $500 \mathrm{nM}$ DHT in methanol was added to $100 \mathrm{~mL}$ of water samples (milliQ, AW, and WWTP water) allowing the interaction of the hormones with the matrix for $30 \mathrm{~min}$, and extracted as above. The resulting extracts were named water $+\mathrm{E} 2$, water + EE2 or water + DHT.

\subsection{Cell culture and exposure to water extracts}

The AR-EcoScreen cell line served to assess the androgenic activity in water extracts. This cell line was obtained from the Japanese Collection of Research Bioresources Cell Bank. The cells are derived from a Chinese hamster ovary cell line and are stably transfected with a plasmid containing an androgen receptor response element (derived from the rat prostate $\mathrm{C} 3$ gene) fused to a luciferase gene, along with a plasmid encoding the androgen receptor cDNA sequence (Kojima et al., 2003). AR-EcoScreen cells were maintained in DMEM/F-12 supplemented with $10 \% \mathrm{FBS}$, penicillin $\left(100 \mathrm{U} \mathrm{mL}^{-1}\right)$, streptomycin $\left(100 \mathrm{U} \mathrm{ml}^{-1}\right)$, hygromycin $\left(25 \mu \mathrm{g} \mathrm{mL}{ }^{-1}\right)$, and zeocin $\left(50 \mu \mathrm{g} \mathrm{mL}^{-1}\right)$. HER-LUC cells derived from HEK-293 stably expressing sbEr $\alpha$ and luciferase as reporter gene (Muriach et al., 2008) served to assess estrogenic activity. This cell line was maintained in DMEM supplemented with $10 \%$ FBS, $1 \%$ antibiotic mixture (penicillin/streptomycine) and $2 \%$ ultraglutamine. Both cell lines were grown in $75-\mathrm{cm} 2$ flasks under a $5 \% \mathrm{CO}_{2}$ humidified atmosphere at $37{ }^{\circ} \mathrm{C}$. Cells were split weekly after detaching them with $0.5 \%$ trypsin:0.02\% EDTA. Before exposure to water extracts cells were plated in 96-well microtiter plates using $100 \mu \mathrm{L}$ of cell suspension per well at a concentration of $10^{5}$ cells $\mathrm{mL}^{-1}$ (AR-EcoScreen) or $2.5 \times 10^{5}$ cellsmL ${ }^{-1}$ (HER-LUC). The cells were maintained in incubation for $24 \mathrm{~h}$ at $37{ }^{\circ} \mathrm{C}$ and $5 \% \mathrm{CO}_{2}$ allowing them to attach to the bottom of the wells. Thereafter, culture medium was substituted with new cell culture medium containing water extracts and cells were incubated for $24 \mathrm{~h}$. To calculate the total water concentrations to which cells were exposed to, the total water volume used in the extraction process was referred to the volume of cell culture medium used in the exposure experiments $(100 \mu \mathrm{L})$. The water concentrations used in the exposure experiments ranged from 0.013 to $3.3 \mu \mathrm{L}$ of water $\mu \mathrm{L}^{-1}$ medium (i.e. since each well received $100 \mu \mathrm{L}$ medium, it can be assumed that cells were effectively exposed to amounts of water ranging from 1.3 to $330 \mu \mathrm{L}$ ). Positive $(1 \mu \mathrm{M}$ E2, $1 \mu \mathrm{M}$ EE2 or $5 \mathrm{nM}$ DHT) and negative (methanol 1\%) controls (PC, NC, respectively) were included. Controls and each sample concentration were assayed in triplicate in each plate.

\subsection{Screening of estrogenic and androgenic activities}

After $24 \mathrm{~h}$ treatment, cell viability was determined by measuring the cellular metabolic activity by means of the resazurin method (O'Brien et al., 2000). Given that resazurin does not interfere with the luminescence assay, cell viability assays were performed prior to luciferase assays in the same plate (Valdehita et al., 2014). $5 \mu \mathrm{L}$ of the resazurin dye solution (ToxKit8, Sigma-Aldrich, Madrid, Spain) was added to each well, and plates were incubated at $37{ }^{\circ} \mathrm{C}$ and $5 \% \mathrm{CO} 2$ for $90 \mathrm{~min}$. Fluorescence was then read with a Microplate-Reader (Tecan Genios Pro, Männedorf, Switzerland) using $530 \mathrm{~nm}$ and $590 \mathrm{~nm}$ as excitation and emission wavelengths, respectively. As a positive control of cytotoxicity, $1 \mathrm{mM}$ SDS was included. Luciferase activity was then measured using appropriate substrates, as previously described by QuesadaGarcía et al. (2012). Bioluminescence was measured in the culture plates using a luminometer (Tecan Genios Pro, Männedorf, Switzerland).

\subsection{Data analysis}

The results are presented as mean \pm standard error of the mean (SEM) of three independent experiments. Each experiment consisted in the application of adsorbents to water samples. Three independent extracts were obtained from water samples of these experiments and analyzed using the in vitro approaches as previously explained. Results of the reporter gene assay are expressed as percentage of the maximal luciferase response induced by the PCs. Luminiscence data were treated as explained in the OECD TG 458 (OECD, 2016). The luminescence value (luminescence counts per second, LCPS) generated by the control wells that received only vehicle (methanol) was subtracted from the luminescence outputs from PCs and experimental samples. The estimation of the concentration-response function and the calculation of the EC50 (effective concentration 50 , i.e. the concentration causing $50 \%$ of the maximal effect) were done by fitting the luminescence results to a regression equation for a four parameter logistic sigmoidal curve: $\mathrm{y}=\max /[1+(\mathrm{x} / \mathrm{EC} 50) \mathrm{b}]+\min$, (where max is the maximal response observed, $\mathrm{b}$ is the slope of the curve, and $\mathrm{min}$ is the minimal response) using GraphPad Prism version 5 (GraphPad Software, San Diego, CA, USA). In order to assess the efficiency of 
the extraction in the spiking experiments, the signal generated by the EC50 of the pure hormone was compared with this generated by the same concentration after extraction from the matrix. The results are expressed as percentage of the signal generated of the hormone EC50. Hormone equivalents (DHT-Eq) for WWTP sample extract were calculated for each dilution of the extract by interpolating the corresponding luminescence output (light counts per second) values in the appropriate curve. Final DHT-Eqs in WWTP were calculated as the mean of DHT-Eqs detected in the different dilutions of the sample.

\section{Results}

3.1. Evaluation of the efficiency of steroids extraction from different water types by means of the reporter gene assays

Data of hormonal (estrogenic and androgenic) activity of extracts obtained from milliQ and aquaria waters spiked with E2, EE2, or DHT are shown in Fig. 1 and in Table 1. The comparison of the induction of estrogenicity caused by these extracts with the estrogenic activity induced by E2 allowed us to assess the efficiency of the hormone extraction. The potency of the estrogenic response induced by extracts from milliQ and AW spiked with E2 (Fig. 1A, Table 1) was close to that produced by pure E2. Since the dose response curves were parallel we can assess the extraction efficiency by comparing the amplitude of the curve for the highest concentration of hormone used. It is observed that efficiency of extraction was also close to $100 \%$ for milliQ and AW respectively. As expected, EE2 presented the same recovery behavior, with $\mathrm{EC}_{50}$ values of the EE2 spiked water extracts similar to $\mathrm{EC}_{50}$ of the pure EE2 (Fig. 1B, Table 1). In the AR-EcoScreen cell line, extracts of waters (milliQ and AW) spiked with DHT induced a response dependent on the applied dose. The highest difference between the $\mathrm{EC}_{50}$ of DHT and these of water extracts corresponded to AW, that was three times that of the former (Table 1). The efficiency of the extraction was maximal in all cases (Fig. 1C, Table 1).

\subsection{Evaluation of the efficiency of PAC, AHS and ZEO treatments on the steroids removal from waters}

The efficiency of the three substrates to remove estrogenic and androgenic activities was assessed in the first place by applying them to milliQ and AW spiked with E2, EE2, or DHT. Results are shown in Fig. 2 and Table 2. Only PAC was able to remove almost completely the hormonal activities with water, leading to increases in the values of EC50. The amplitude of the curves for the maximal concentrations of the hormones was compared to estimate in the worst case scenario the percentage of removal that varied for estrogenic activities between $86.4 \%$ (for milliQ waters spiked with EE2) and 99.8\% (for AW spiked with E2), and for androgenic activities between $67.7 \%$ (for milliQ water spiked with DHT) and $92.1 \%$ (for AW spiked with DHT). However, low removal efficiencies were observed for the other treatments, thus invalidating its application as a complementary water treatment under the established conditions.

\subsection{Estrogenic and androgenic activity in water samples from WWTP}

In addition to the laboratory treatments described before, the capacity of the different substrates to remove hormonal activities was assessed in real WWTP effluent samples. From the four WWTP effluents collected, two of them showed androgenic activities but no estrogenic activity was observed. Since our interest was in evaluating the capacity of removal of hormone activities by the
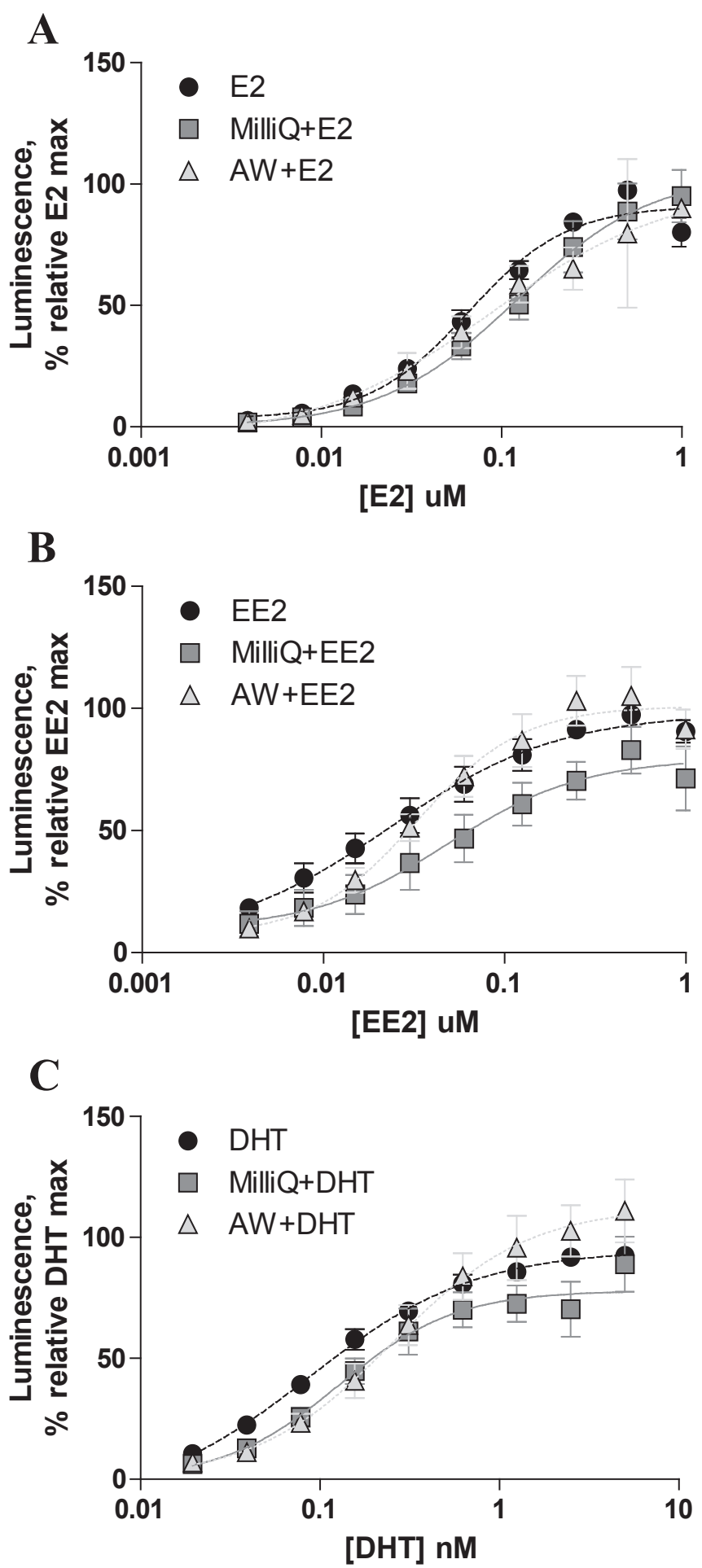

Fig. 1. Luminescence induced by serial concentrations of hormones and by the extracts of waters (milliQ and AW) spiked with the corresponding hormones. (A) E2 and extracts of waters spiked with E2. (B) EE2 and extracts of waters spiked with EE2. (C) DHT and waters spiked with DHT. Values are mean \pm SEM $(n=3)$.

substrates, and taking into account the structural similarities between androgens and estrogens, we decided to continue concentrating our efforts on androgen activities assuming that the obtained results could be applicable in general to estrogenicity and androgenicity.

First of all, WWTP waters not showing any androgenic activity 
Table 1

Potency $\left(\mathrm{EC}_{50}\right)$ and recovery percentage of pure E2, EE2 and DHT and of extracts of waters spiked with these hormones. Values represent the mean $\pm \operatorname{SEM}(n=3)$.

\begin{tabular}{|c|c|c|c|c|c|}
\hline & \multicolumn{2}{|c|}{$\begin{array}{l}\text { Estrogenicity (HER- } \\
\text { LUC) }\end{array}$} & & \multicolumn{2}{|c|}{$\begin{array}{l}\text { Androgenicity (AR- } \\
\text { EcoScreen) }\end{array}$} \\
\hline & EC50 $(\mu \mathrm{M})$ & \% Recovery & & EC50 (nM) & \% Recovery \\
\hline E2 pure & 0.065 & 100 & DHT pure & 0.087 & 100 \\
\hline MilliQ+E2 & 0.121 & 97.5 & MilliQ+DHT & 0.127 & 96.1 \\
\hline $\mathrm{AW}+\mathrm{E} 2$ & 0.086 & 92.3 & $\mathrm{AW}+\mathrm{DHT}$ & 0.254 & 119.9 \\
\hline EE2 pure & 0.023 & 100 & & & \\
\hline MilliQ+EE2 & 0.048 & 90.2 & & & \\
\hline $\mathrm{AW}+\mathrm{EE} 2$ & 0.032 & 107.7 & & & \\
\hline
\end{tabular}
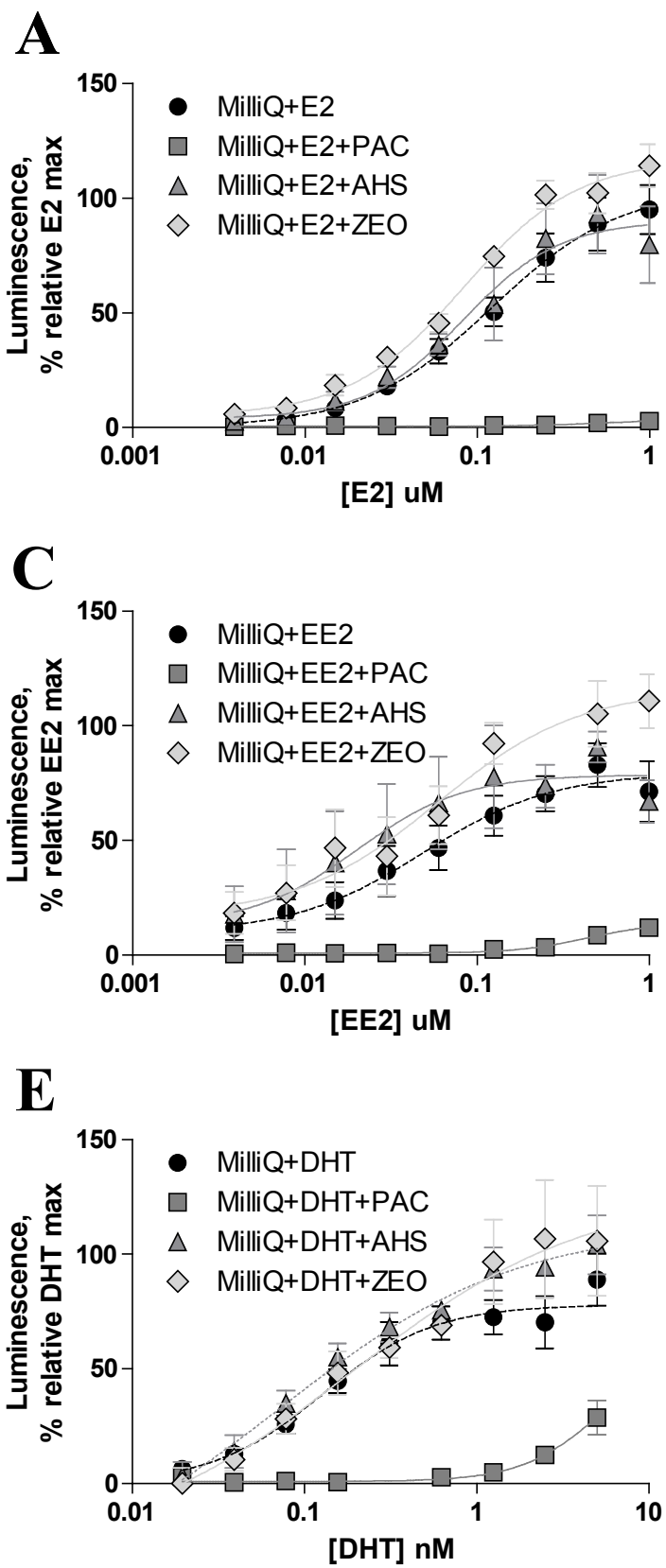

were spiked with DHT and subjected to the extraction process as described. Results are shown in Fig. $3 \mathrm{~A}$. The $\mathrm{EC}_{50}$ of the spiked water extracts was approximately twice $\left(\mathrm{EC}_{50}=0.170 \mathrm{nM}\right)$ this of the pure DHT $\left(\mathrm{EC}_{50}=0.087 \mathrm{nM}\right)$. The efficiency of the extraction was maximal when comparing the amplitude of the curves for the maximal concentration of DHT. Therefore, we considered that the extraction androgenic activity from WWPT effluents was appropriate to assess the efficiency of the treatments.

Androgenic activity in WWTP water effluents (designated as WWTP A and B) before application of treatments appears in Fig. 3B. Here we show the maximal androgenic activity observed at the maximal concentration of effluent in medium $(3.3 \mathrm{~mL}$ effluent

B
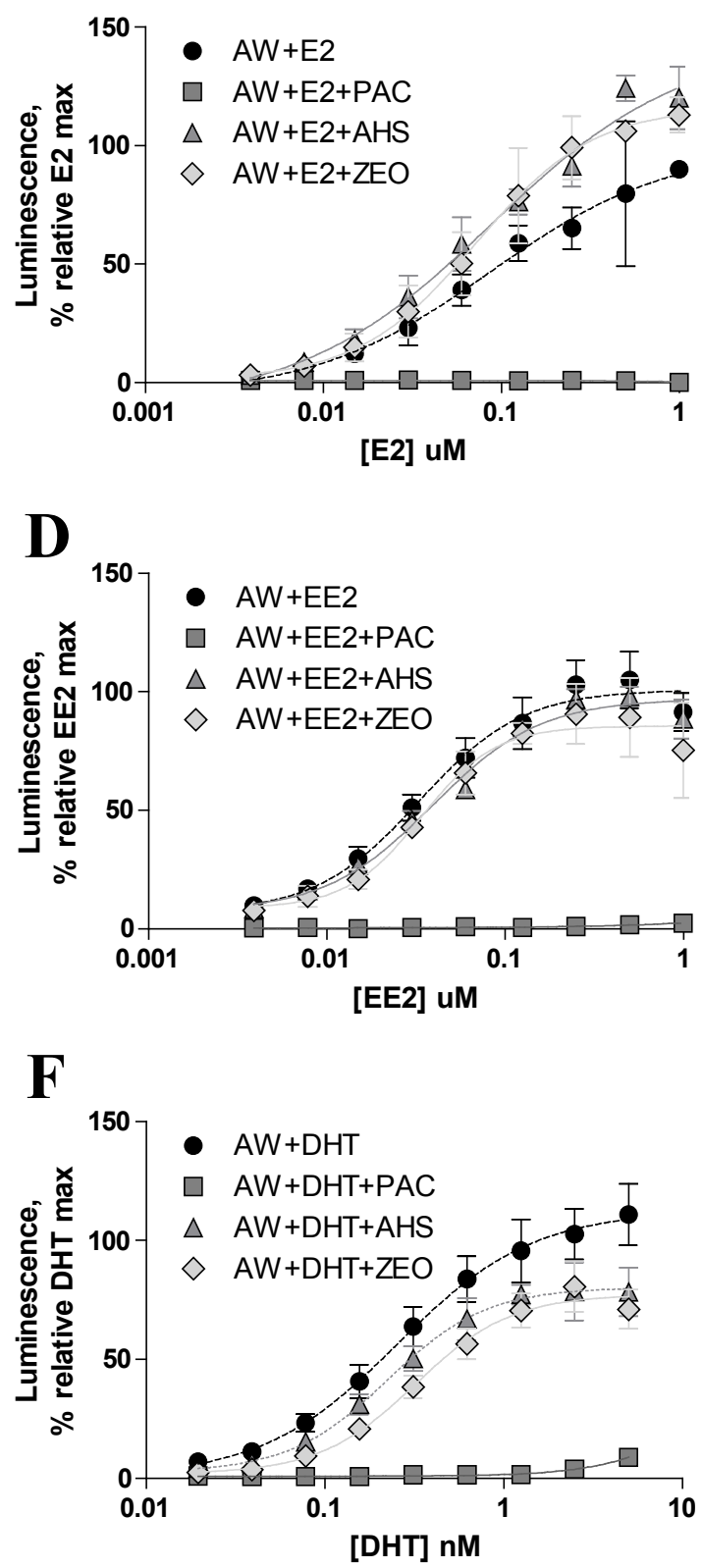

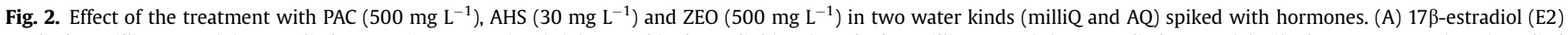

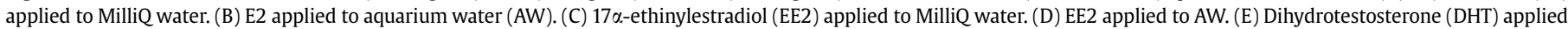
to MilliQ water. (F) DHT applied to AW. Values represent the mean \pm SEM $(n=3)$. 
Table 2

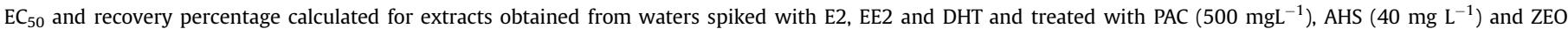
(500 $\left.\mathrm{mg} \mathrm{L}^{-1}\right)$. Values represent the mean $\pm \operatorname{SEM}(n=3)$.

\begin{tabular}{|c|c|c|c|c|c|c|c|}
\hline & \multicolumn{3}{|c|}{ Estrogenicity (HER-LUC) } & & \multicolumn{3}{|c|}{ Androgenicity (AR-EcoScreen) } \\
\hline & $\mathrm{EC}_{50}(\mu \mathrm{M})$ & Recovery (\%) & Removal efficiency (\%) & & $\mathrm{EC}_{50}(\mathrm{nM})$ & Recovery (\%) & Removal efficiency (\%) \\
\hline MilliQ+E2 & 0.121 & 100 & & MilliQ+DHT & 0.127 & 100 & \\
\hline MilliQ+E2+PAC & 0.595 & 2.9 & 97.0 & MilliQ+DHT+PAC & - & 32.3 & 67.7 \\
\hline MilliQ + E2 + AHS & 0.082 & 97.8 & 2.1 & MilliQ+DHT+AHS & 0.073 & 117.1 & - \\
\hline MilliQ+E2+ZEO & 0.083 & 120.0 & - & MilliQ+DHT+ZEO & 0.185 & 119.9 & - \\
\hline $\mathrm{AW}+\mathrm{E} 2$ & 0.086 & 100 & & $\mathrm{AW}+\mathrm{DHT}$ & 0.254 & 100 & \\
\hline $\mathrm{AW}+\mathrm{E} 2+\mathrm{PAC}$ & - & 0.1 & 99.8 & $\mathrm{AW}+\mathrm{DHT}+\mathrm{PAC}$ & - & 7.9 & 92.1 \\
\hline $\mathrm{AW}+\mathrm{E} 2+\mathrm{AHS}$ & 0.088 & 133.5 & - & $\mathrm{AW}+\mathrm{DHT}+\mathrm{AHS}$ & 0.224 & 70.8 & 29.1 \\
\hline $\mathrm{AW}+\mathrm{E} 2+\mathrm{ZEO}$ & 0.072 & 125.4 & - & $\mathrm{AW}+\mathrm{DHT}+\mathrm{ZEO}$ & 0.329 & 72.8 & 27.1 \\
\hline MilliQ+EE2 & 0.048 & 100 & & & & & \\
\hline MilliQ+EE2+PAC & 0.436 & 13.5 & 86.4 & & & & \\
\hline MilliQ+EE2+AHS & 0.020 & 103.0 & - & & & & \\
\hline MilliQ+EE2+ZEO & 0.059 & 119.5 & - & & & & \\
\hline $\mathrm{AW}+\mathrm{EE} 2$ & 0,032 & 100 & & & & & \\
\hline $\mathrm{AW}+\mathrm{EE} 2+\mathrm{PAC}$ & - & 2.3 & 97.6 & & & & \\
\hline $\mathrm{AW}+\mathrm{EE} 2+\mathrm{AHS}$ & 0.039 & 93.3 & 6.6 & & & & \\
\hline $\mathrm{AW}+\mathrm{EE} 2+\mathrm{ZEO}$ & 0.033 & 85 & 15 & & & & \\
\hline
\end{tabular}

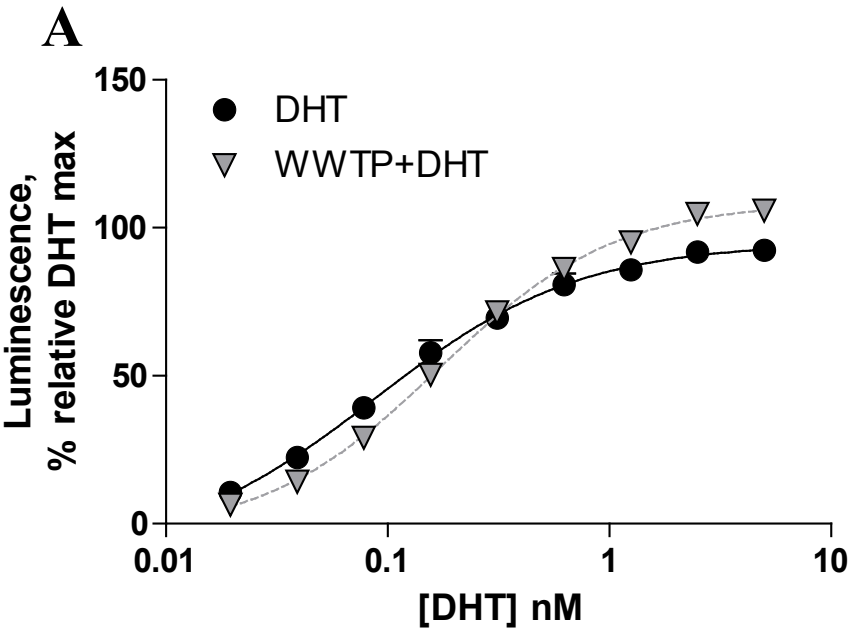

B

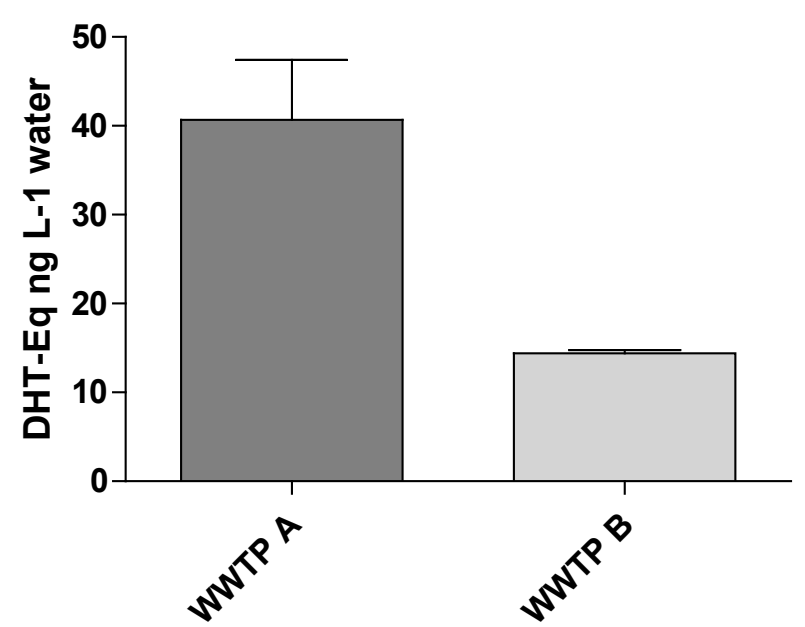

Fig. 3. (A) Luminiscence induced by dihydrotestosterone (DHT) and by extracts of WWTP water not showing originally any androgenic activity spiked with DHT. (B) Global androgenicity induced by extracts of two WWTP (WWTP A and B) effluents. Values are mean \pm SEM $(n=3)$.
$\mathrm{mL}^{-1}$ medium) expressed as DHT-Eq (Table 3).

The efficacy of the three treatments for reducing the androgenic activity present in two waste water samples is shown in Fig. 4 and Table 3. In contrast to the results obtained from water samples spiked in laboratory, the removal efficiency of PAC was only $12.3 \%$ and $6.9 \%$ for WWTP A and B, respectively. However, satisfactory results were revealed by treatment with ZEO showing relevant removal efficiencies of $60 \%$ and $48.9 \%$ for WWTP A and B, respectively (Table 3).

\section{Discussion and conclusion}

Several approaches exist to monitor the presence of EDCs in surface waters. Traditional assessment of water contamination has been based on chemicals analyses, identifying and quantifying individual compounds, but this approach has some limitations (Caldwell et al., 2012), related with the fact that chemical analyses are not able to evidence the presence of chemicals below the limit of detection neither to reflect the interactions (antagonistic, agonistic, additive) among the plethora of substances present in environmental samples (Valdehita et al., 2016). Therefore, the exclusive use of chemical analyses in evaluating the global toxicity or hormonal activity of environmental samples can lead to important misinterpretation of the results. Bioassays, particularly those based on in vitro techniques, such as those applied here, have the enormous advantage of assessing global endocrine activity, thus any contribution from any substance, even if present at trace levels,

Table 3

DHT-Eq present in WWTP A and B effluents, before and after treatment with PAC AHS and ZEO. Values are mean $\pm \operatorname{SEM}(n=3)$.

\begin{tabular}{lll}
\hline & \multicolumn{2}{l}{ Androgenicity (AR-EcoScreen) } \\
\cline { 2 - 3 } & DHT-Eq $(\mathrm{ng} / \mathrm{mL})$ & Removal efficiency $(\%)$ \\
\hline WWTP A & 0.040 & \\
WWTP A+PAC & 0.035 & 12.3 \\
WWTP A+AHS & 0.043 & - \\
WWTP A+ZEO & 0.016 & 60 \\
WWTP B & & \\
WWTP B+PAC & 0.014 & - \\
WWTP B+AHS & 0.013 & 6.9 \\
WWTP B+ZEO & 0.015 & - \\
\hline
\end{tabular}


$\mathbf{A}$
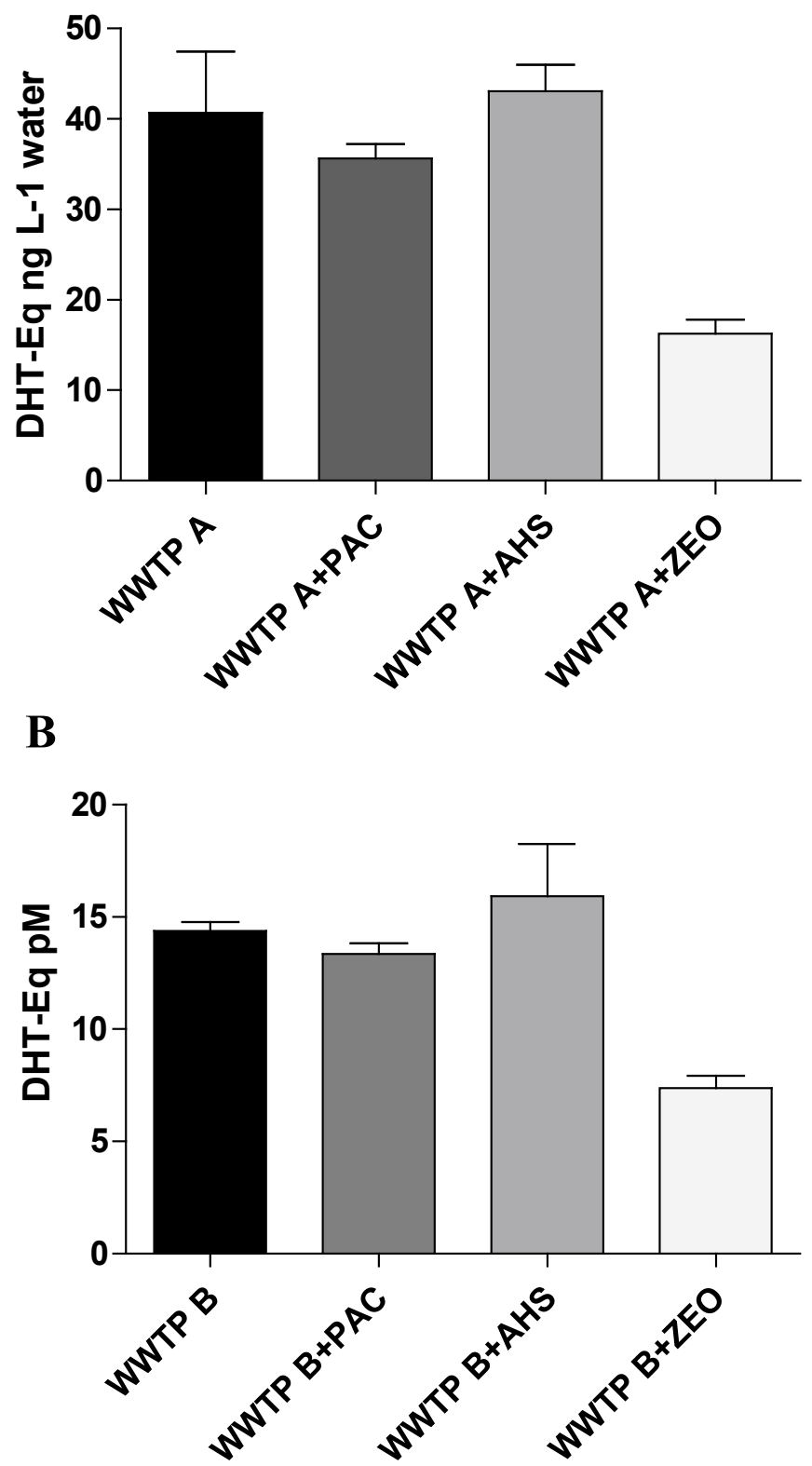

Fig. 4. Androgenicity induced by the original extracts of two WWTP (WWTP A and B) effluents and by extracts of the same waters after treatment with PAC $\left(500 \mathrm{mg} \mathrm{L}^{-1}\right)$, AHS (40 $\left.\mathrm{mg} \mathrm{L}^{-1}\right)$, and ZEO (500 $\left.\mathrm{mg} \mathrm{L}^{-1}\right)$. Values are mean \pm SEM $(\mathrm{n}=3)$.

is recognized, and all the interactions are reflected in the final readout (Valdehita et al., 2014 and Valdehita et al., 2016). In the present work, in vitro approaches based on the use of cell lines stably transfected with the genes of interest and with reporter genes were used to detect estrogenic and androgenic activities and, hence, to evaluate the removal efficiency of hormonal activities by PAC, AHS and ZEO treatments.

According to Chang et al. (2009) the on-going EDCs research trends can be classified into three major categories, such as the identification and determination of the effects of EDCs, the development and improvement of analytical methods, and the application and modification of water treatment options for the removal of EDCs. In this sense, the investigation to find simple and inexpensive treatments that could be potentially applied in sectors or regions with limited resources should be further encouraged.
It has been reported that PAC is able to remove through adsorption processes a number of EDCs, including E1, E2, EE2, E3 and bisphenol A (Joseph et al., 2013; Schenck et al., 2012; Westerhoff et al., 2005; Yoon et al., 2003). In the past few years, many researchers have demonstrated that AC also has a strong capability of removing a broad range of representative EDCs for artificial and real waste water in the laboratory and pilot and fullscale plants (Choi et al., 2005; Fukuhara et al., 2006; Tsai et al., 2006; Snyder et al., 2007). In this paper, the significant PAC removal efficiency of endocrine disruptors (E2, EE2 and DHT) from different types of waters artificially contaminated was also confirmed. However, the same treatment did not show the same effectiveness when applied to actual WWTP effluent samples, in which PAC treatment only provoked a slight decrease in androgenic activity as measured by in vitro bioassays. However, in accordance with Conley et al. (2016), the adsorption efficiency can vary widely depending on a number of parameters including water quality. Endocrine activity detected in effluents cannot be assigned to a single hormone (as it was the case in the clean waters use in the present work) but to a number of substances that show additive, agonistic and antagonistic interactions. Normally, these hormones exhibit some hydrophobicity and tend to interact with particles in suspension (Aris et al., 2014) and to accumulate in sediments. It is highly possible that effluents used here had a high number of micro and nanoparticles that sequestered the substances with hormonal activity avoiding their accommodation in PAC porous. In addition to this, other chemicals present in waste waters could also have interacted with the endocrine active substances contributing to their inability to enter the carbon pores.

Strikingly, natural ZEO that showed a limited efficacy in removing endocrine activities from artificially contaminated waters, were able to provoke an important reduction of androgenic activity in WWTP effluents. Commercial zeolites with different surface and pore properties have been increasingly studied for the adsorption of dissolved pollutants in water and/or waste water (Metes et al., 2004). However, such kind of applications have concentrated so far on the removal of metals (Koshy and Singh, 2016) and dyes (Tsai et al., 2009). To the extent of our knowledge, this is the first report on its effectiveness in reducing endocrine disruption in waste waters. ZEO exhibited a higher efficacy than PAC in removing hormonal activities from effluents. As indicated previously, it is possible that substances with endocrine activity could be complexed with microparticles present in waste water and that these particles were retained by ZEO.

Regarding the possible complexation of endocrine disruptors with AHS, previously demonstrated by Botero et al. (2011), in the present work this substrate did not show any influence on the reduction of estrogenic or androgenic activities. Instead, a maximization effect on estrogenic activity was observed for a few tests. The possibility that humic substances can act or enhance endocrine disruption activity was also reported in other studies (Ren et al., 2016; Silva et al., 2016).

In conclusion, we have observed a good efficiency of PAC in the removal of specific hormones from different kinds of waters artificially contaminated, a fact that did not ensure its good performance in the treatment of actual effluent samples. ZEO was investigated for the first time as a possible treatment for the removal of EDCs, and although it had a limited efficiency in the removal of E2, EE2, and DHT added to waters, however it has achieved significant reduction of androgenic activity in actual waste waters. AHS did not show to be effective in any of the tests. Probably, real effluents contain a plethora of substances with mixed molecular structures that will interact among them preventing or favoring the retention of endocrine active substances by the matrices used in this study. The possibility that the complexation of 
hormones with other molecules could prevent an appropriate activity of the applied treatments must also be explored.

\section{Acknowledgments}

The authors are grateful to the São Paulo Research Foundation (FAPESP, Portuguese: Fundação de Amparo à Pesquisa do Estado de São Paulo), process number 2012/14583-5, for the financial support that made this work possible. They are also grateful to the Spanish National Institute for Agricultural and Food Research and Technology (INIA) for receiving the doctoral student Juliana PolloniSilva (FAPESP scholarship number 2014/22733-2). The authors also acknowledge the help of INIA project RTA2012-00053-00-00 supported by the European Regional Development Fund.

\section{References}

Ali, I., Gupta, V.K., 2006. Advances in water treatment by adsorption technology. Nat. Protoc. 1 (6), 2661-2667.

Andersen, H.R., Anderson, A.M., Arnold, S.F., Autru, H., Barfoed, M., Beresford, N.A., et al., 1999. Comparison of short-term estrogenicity tests for identification of hormone-disrupting chemicals. Environ. Health Persp. 107, 89-108.

Aris, A.Z., Shamsuddin, A.S., Praveena, S.M., 2014. Occurrence of 17a-ethynylestradiol (EE2) in the environment and effect on exposed biota: a review. Environ. Intern. 69, 104-119.

Auriol, M., Filali-Mehnassi, Y., Tyagi, R.D., Adams, C.D., Surampalli, R.Y., 2006. Endocrine disrupting compounds removal from wastewater a new challenge. Process Biochem. 41, 525-539.

Baronti, C., Curini, R., D’Ascenzo, G., Di Corcia, A., Gentili, A., Samperi, R., 2000. Monitoring natural and synthetic estrogens at activated sludge sewage treatment plants and in a receiving river water. Environ. Sci. Technol. 34 (24), 5059-5066.

Botero, W.G., Oliveira, L.C., de Cunha, B.B., Oliveira, L.K., de Goveia, D., Rocha, J.C., Fraceto, L.F., Rosa, A.H., 2011. Characterization of the interactions between endocrine disruptors and aquatic humic substances from tropical rivers. J. Braz. Chem. Soc. 22 (6), 1103-1110.

Caldwell, D.J., Mastrocco, F., Anderson, P.D., Lange, R., Sumpter, J.P., 2012. Predictedno-effect concentrations for the steroid estrogens estrone, 17 ß-estradiol, estriol, and $17 \alpha$-ethinylestradiol. Environ. Toxicol. Chem. 31 (6), 1396-1406.

Chang, H., Choo, K., Lee, B., Choi, S., 2009. The methods of identification, analysis, and removal of endocrine disrupting compounds (EDCs) in water. J. Hazard. Mater. 172, 1-12.

Choi, K.J., Kim, S.G., Kim, C.W., Kim, S.H., 2005. Effects of activated carbon types and service life on removal of endocrine disrupting chemicals: amitrol, nonylphenol, and bisphenol A. Chemosphere 58, 1535-1545.

Combalbert, S., Bellet, V., Dabert, P., Bernet, N., Balaguer, P., Hernandez-Raquet, G., 2012. Fate of steroid hormones and endocrine activities in swine manure disposal and treatment facilities. Water Res. 46, 895-906.

Conley, J.M., Evans, N., Mash, H., Rosenblum, L., Schenck, K., Glassmeyer, S., Furlong, E.T., Kolpin, D.W., Wilson, V.S., 2016. Comparison of in vitro estrogenic activity and estrogen concentrations in source and treated waters from 25 U.S. drinking water treatment plants. Sci. Total Environ. http://dx.doi.org/10.1016/ j.scitotenv.2016.02.093. ISSN 0048-9697.

D’Ascenzo, G., DiCorcia, A., Gentili, A., et al., 2003. Fate of estrogen conjugates in municipal sewage transport and facilities. Sci. Total Environ. 302, 199-209.

de Costa, P.D., Furmanski, L.M., Dominguini, L., 2015. Produção, caracterização e aplicação de carvão ativado de casca de nozes para adsorção de azul de metileno. Ver. Virtual Quim. 7, 1272-1285.

Dias, A.C.V., Gomes, F.W., Bila, D.M., Sant'Anna Jr., G.L., Dezotti, M., 2015. Analysis of estrogenic activity in environmental waters in Rio de Janeiro state (Brazil) using the yeast estrogen screen. Ecotox. Environ. Safe. 120, 41-47.

Fukuhara, T., Iwasaki, S., Kawashima, M., Shinohara, O., Abe, I., 2006. Adsorbability of estrone and $17 \beta$-estradiol in water onto activated carbon. Water Res. 40 (2), $241-248$.

Grover, D.P., Balaam, J., Pacitto, S., Readman, J.W., White, S., Zhou, J.L., 2011. Endocrine disrupting activities in sewage effluent and river water determined by chemical analysis and in vitro assay in the context of granular activated carbon upgrade. Chemosphere 84 (10), 1512-1520.

Jarošová, B., Bláha, L., Giesy, J.P., Hilscherová, K., 2014. What level of estrogenic activity determined by in vitro assays in municipal waste waters can be considered as safe? Environ. Inter. 64, 98-109.

Jiang, J.Q., Yin, Q., Zhou, J.L., Pearce, P., 2005. Occurrence and treatment trials of endocrine disrupting chemicals (EDCs) in wastewaters. Chemosphere 61, $544-550$.

Joseph, L., Boateng, L.K., Flora, J.R.V., Park, Y., Son, A., Badawy, M., Yoon, Y., 2013. Removal of bisphenol A and $17 \alpha$-ethinyl estradiol by combined coagulation and adsorption using carbon nanomaterials and powdered activated carbon. Sep.. Purif. Technol. 107, 37-47.

Kojima, H., Iida, M., Katsura, E., Kanetoshi, A., Hori, Y., Kobayashi, K., 2003. Effects of a diphenyl ether-type herbicide, chlornitrofen, and its amino derivative on androgen and estrogen receptoractivities. Environ. Health Perspect 111, 497-502.

Koshy, N., Singh, D.N., 2016. Fly ash zeolites for water treatment applications J. Environ. Chem. Eng. 4 (2), 1460-1472.

Metes, A., Kovačević, D., Vujević, D., Papić, S., 2004. The role of zeolites in wastewater treatment of printing inks. Water Res. 38 (14-15), 3373-3381.

Muriach, B., Cerdá-Reverter, J.M., Gómez, A., Zanu, S., Carrillo, M., 2008. Molecular characterizationand central distribution of the estradiol receptor alpha (ER $\alpha)$ in the sea bass (Dicentrarchus labrax). J. Chem. Neuroanat 35, 33-48.

Nascimento, M., Soares, P.S.M., Souza, V.P.D., 2009. Adsorption of heavy metal cations using coal fly ash modified by hydrothermal method. Fuel 88 (9), 1714-1719.

O'Brien, J., Wilson, I., Orton, T., Pognan, F., 2000. Investigation of the alamar blue (resazurin) fluorescentdye for the assessment ofmammalian cell cytotoxicity Eur. J. Biochem 267, 5421-5426.

OECD, 2016. Test Guide for testing of chemicals No. 458:Stably Transfected Human Androgen Receptor Transcriptional Activation Assay for Detection of Androgenic Agonist and Antagonist Activity of Chemicals.

Petrus, R., Warchoł, J.K., 2005. Heavy metal removal by clinoptilolite. An equilibrium study in multi-component systems. Water Res. 39 (5), 819-830.

Quesada-García, A., Valdehita, A., Fernández-Cruz, M.L., Leal, E., Sánchez, E., MartínBelinchón, M., Cerdá-Reverter, J.M., Navas, J.M., 2012. Assessment of estrogenic and thyrogenic activities in fish feeds. Aquaculture 338-341, 172-180.

Redding, A.M., Cannon, F.S., Snyder, S.A., Vanderford, B.J., 2009. A QSAR-like analysis of the adsorption of endocrine disrupting compounds, pharmaceuticals, and personal care products on modified activated carbons. Water Res. 43, 3849-3861.

Ren, D., Huang, B., Xiong, D., He, H., Meng, X., Pan, X., 2016. Photosensitized degradation of $17 \beta$-estradiol and $17 \alpha$-ethinylestradiol: role of humic substances Fractions. J. Environ. Qual. 45 (2), 693-700.

Schenck, K., Rosenblum, L., Wiese, T., Wymer, L., Dugan, N., Williams, D., Mash, H. Merriman, B., Speth, T., 2012. Removal of estrogens and estrogenicity through drinking water treatment. J. Water Health 10 (1) 43-55.

Scholz, S., Renner, P., Belanger, S.E., Busquet, F., Davi, R., Demeneix, B.A., et al., 2013. Alternatives to in vivo tests to detect endocrine disrupting chemicals (EDCs) in fish and amphibians - screening for estrogen, androgen and thyroid hormone disruption. Crit. Rev. Toxicol. 43, 45-47.

Silva, C.P., Lima, D.L.D., Groth, M.B., Otero, M., Esteves, V.I., 2016. Effect of natura aquatic humic substances on the photodegradation of estrone. Chemosphere $145,249-255$.

Snyder, S.A., Adham, S., Redding, A.M., Cannon, F.S., DeCarolis, J., Oppenheimer, J. Wert, E.C., Yoon, Y., 2007. Role of membranes and activated carbon in the removal of endocrine disruptors and pharmaceuticals. Desalination 202, $156-181$.

Stasinakis, A.S., Gatidou, G., Mamais, D., Thomaidis, N.S., Lekkas, T.D., 2008 Occurrence and fate of endocrine disrupters in Greek sewage treatment plants. Water Res. 42, 1796-1804.

Sun, W.L., Ni, J.R., Xu, N., Sun, L.Y., 2007. Fluorescence of sediment humic substance and its effect on the sorption of selected endocrine disruptors. Chemosphere 66 (4), 700-707.

Ternes, T.A., Stumph, M., Mueller, J., Haberer, K., Wilken, R.D., Servos, M., 1999. Behavior and occurrence of estrogens in municipal sewage treatment plants. I. Investigations in Germany. Can. Braz. Sci. Total Environ. 225, 81-90.

Tsai, W.T., Hsu, H.C., Su, T.Y., Lin, K.Y., Lin, C.M., 2006. Adsorption characteristics of bisphenol-A in aqueous solutions onto hydrophobic zeolite. J. Colloid Interf. Sci. 299, 513-519.

Tsai, W., Hsien, K., Hsu, H., 2009. Adsorption of organic compounds from aqueous solution onto the synthesized zeolite. J. Hazard. Mater. 166 (2-3), 635-641.

Valdehita, A., Quesada-García, A., Delgado, M.M., Martín, J.V., García-González, M.C. Fernández-Cruz, M.L., Navas, J.M., 2014. In vitro assessment of thyroidal and estrogenic activities in poultry and broiler manure. Sci. Total Environ. 472 630-641.

Valdehita, A., Fernández-Cruz, M.L., González-Gullon, M., Becerra-Neira, E. Delgado, M.M., García-González, M.C., Navas, J.M., 2016. Androgens and androgenic activity in broiler manure assessed by means of chemical analyses and in vitro bioassays. Environ. Toxicol. Chem. 9999 (9999), 1-9.

Westerhoff, P., Yoon, Y., Snyder, S., Wert, E., 2005. Fate of endocrine-disruptor pharmaceutical, and personal care product chemicals during simulated drinking water processes. Environ. Sci. Technol. 39, 6649-6663.

Ying, G., Kookana, R.S., Ru, Y., 2002. Occurrence and fate of hormone steroids in the environment. Environ. Inter. 28 (6), 545-551.

Yoon, Y., Westerhoff, P., Snyder, S.A., Esparza, M., 2003. HPLC-fluorescence detection and adsorption of bisphenol A, 17b-estradiol, and 17a-ethynyl estradiol on powdered activated carbon. Water Res. 37, 3530-3537.

Zhang, Y., Zhou, J.L., 2005. Removal of estrone and 17b-estradiol from water by adsorption. Water Res. 39, 3991-4003.

Zhang, Y., Zhou, J.L., 2008. Occurrence and removal of endocrine disrupting chemicals in wastewater. Chemosphere 73, 848-853.

Zhang, Y., Zhou, J.L., Ning, B., 2007. Photodegradation of estrone and 17b-estradiol in water. Water Res. 41, 19-26.

Zhou, J.L., Zhang, Z.L., Banks, E., Grover, D., Jiang, J.Q., 2009. Pharmaceutical residues in wastewater treatment works effluents and their impact on receiving river water. J. Hazard. Mater. 166, 655-661. 